\title{
Systematic Literature Review of Disruption Era in Indonesia: The Resistance of Industrial Revolution 4.0
}

\author{
M. Fadilurrahman' ${ }^{1}$ Tahta Kurniawan ${ }^{2}, \operatorname{Ramadhani}^{3}$, Misnasanti $^{4}$, Syahrial Shaddiq $^{5}$ \\ Universitas Negeri Yogyakarta (UNY), Yogyakarta, Indonesia ${ }^{I}$ \\ Universitas Muhammadiyah Yogyakarta (UMY), Yogyakarta, Indonesia ${ }^{2,3}$ \\ Universitas Islam Negeri (UIN) Antasari, Banjarmasin, Indonesia 4 \\ Universitas Islam Indonesia (UII), Yogyakarta, Indonesia ${ }^{5}$ \\ E-mail: m.fadilurrahman.2017@student.uny.ac.id, tahtakurniawan@gmail.com², ramadhanii150199@gmail.com³, \\ misna.santi@gmail.com4,17931001@students.uii.ac.id ${ }^{5}$
}

\begin{abstract}
The plethora of research in the multidisciplinary fields has been proved the disruption era. However, it might be several boundaries in the global context. Thus, this research attempts to identify dominant fields which consist of implementing the law, governance, management trajectory, and system of higher education in Indonesia. Furthermore, the qualitative method of the systematic literature review is used to examine the implication, and therefore this study produces four findings. Firstly, the most prominent enabling contexts are to ensure the implementation of the law and the conceptualization of policies. Secondly, adopting effective and efficient bureaucracy bases on electronic governance (e-governance). Thirdly, management trajectory has been aimed to fill the gaps in this context. Finally, this study also intends to unveil preliminary actions toward higher education system by networking infrastructures. The outcomes might be considered as pathways for accelerating the progress related to authorities, companies, and institutions. By way of conclusion, in order to attain better provision, measuring the process of Indonesia disruption realm is a critical phase to elucidate the current circumstance, elaborate the gaps, and foresee the priority actions concerning the disruption era in Indonesia.
\end{abstract}

Keywords-Disruption era, Indonesia, implementing policies, management, education system.

\section{Introduction}

Globalisation has entered a new era called the 4.0 industrial revolution, according to the fourth world industrial revolution has gone through four stages of metamorphosis. Industrial revolution 1.0 in the $18^{\text {th }}$ century, through the discovery of steam engines that enabled mass production of goods, industrial revolution 2.0 in the $19^{\text {th }}-20^{\text {th }}$ century through the use of electricity, which made production costs cheaper, industrial revolution 3.0 in 1970 through computerisation, industrial revolution 4.0 began in $2012 \mathrm{~s}$ through internal engineering and internet of things (IoT) as the backbone of the movement and connectivity of humans and machines [1].

The purpose of this study is to research efforts to be identified as the dominant field consisting of the application of the law, governance, management trajectory, and the higher education system in Indonesia. Contributions in research, namely in theory contributions add to the collection of knowledge from theories relating to law, governance, management trajectories, and existing higher education systems. Furthermore, the practical gap in this study is to provide practitioners with an overview of the law, governance, management trajectory, and existing higher education systems, so that they are more aware and able to comply with them well [2].

The results of this research that has been done are findings: 1) the new theories and conceptualization about the law, 2) in the management trajectory, the resistance of industrial revolution 4.0 impacted changes dynamically to managing the people in the organization, especially at the universities in the world. Besides, in the finance, marketing, operation of the system of higher education also changes every single day. Furthermore, we need new theories and practices to manage the turbulence of un-linear changes in every sector of the management area, for instance: human resource, strategic, operation, innovation, finance, and marketing at the system in the universities to tackle the collapse of higher education in these eras, 3) the excellence of e-governance in Indonesia, and 4) the essentials of system of higher education with preferential quality, precisely in Indonesia [3].

Implications in the field of science, namely giving an impact on scientific contributions, known as the body of knowledge, managerial implications, namely management of education management systems that consider various aspects, namely: legal issues, governance, management trajectory, and higher education system in the revolutionary era 4.0. Suggestions for future research can be examined in the context of community 5.0. Thus, the introduction of this research paper, for further study is continued in the next section [4].

\section{Literature Review}

\section{II.1. Legal Aspects}

In legal and ethical scope, these days of digital economy, Intelligent machines are endangering routine and repetitive professions such as lawyers (and legal staff), accountants, auditors, cashiers, drivers, and fast food. The others sides also become vulnerable, for example, the rules and regulations implementations in the cyber security sector for data protections. It can be seen as a risk in fraudulent data generation technologies, undisclosed backdoors, and illegal economy like the dark web. Because of lack of regulation and rules in this era, almost all of the sector is being easy to get alternated which can impact on politics, economy and law. However, the first and foremost, disruption era affects powerfully in trade and intellectual property law, especially artificial intelligence (AI) [5]. 
Moreover, even though in intellectual property law in Indonesia there is no regulation related to blockchain as intellectual property, the governmenttakes action to regulate it by Act of Bank Indonesia (BI) no. 18 in 2016 about Transaction and Payment. Therefore, blockchain technology is highly promising in its potential applications in various IPrelated felds. From the initial establishment of an intellectual property right, along its legal journey to registries, licensing and enforcement, blockchain technology can be used to achieve various worthy goals [6].

\section{II.2. Electronic Governance Aspects}

Governments throughout the country are working to provide the best service to their people. But behind that the government still has obstacles to achieving the desired target, among others regarding the system of government, ways of making public policy, lack of coordination between institutions and various information between sectors and the lack of Information and Communication Technology (ICT) that is considered adequate [7].

In recent years, governments in various countries have tried to reform and carry out e-governance development initiatives, with the hope that all levels of citizens can access them. This concept attracts considerable attention, especially in terms of public administration in the era of industrial revolution 4.0, which aims to improve efficiency and effectiveness in public services and bureaucratic processes [8].

Through the concept of e-governance, society and the government will get benefits and opportunities such as faster time and more suppressed costs. The application of this concept also has its challenges, namely from the human resources (HR) sector that is needed must be the availability of a skilled and qualified workforce in their field. Government organisations also need to focus on improving computer literacy. The government must be serious and focus on increasing the index of e-governance development to the implementation of e-governance [9].

The development of e-governance in other countries especially in Southeast Asia, such as the Thai government which has adopted this concept since 2006, is based on six main topics, namely [10]:

1. Political will,

2. Inter-agency collaboration and social/cultural change,

3. Legal strength,

4. Process agreement,

5. Exchange agreements, and

6. Technical development.

From some of the high focus, it becomes the central element in facilitating "connected government" whose purpose is to maximise e-governance services [10].

\section{II.2.1. Development of E-Governance in Indonesia}

In the process, e-governance in Indonesia began in 2001 since the emergence of Presidential Instruction no. 6 in 2001, precisely on April 24, 2001, concerning Telematics (Telecommunications, Media, and Informatics) which instructed the government to use telematics technology to support good governance to accelerate the process of democracy [11].

In 2003, during the era of President Megawati Soekarno Putri, the government issued a policy that was more focused on the implementation of e-governance, through Presidential Instruction no. 3 in 2003. This presidential instruction contained the strategy of developing egovernment which was also equipped with several instructions and instructions on e-government. E-governance consists of [12]:

- Guide to government portal infrastructure development,

- Management guide for government electronic document systems,

- Guidelines on implementing local government websites etc. As well as the Depkominfo presented various guidelines in 2004 which has become a reference for the implementation of e-governance at the central and regional levels. In this presidential decree, the President explicitly instructed all Ministers, Governors, Mayors, and Regents to build egovernance by coordinating with the Minister of Communication and Information [13].

\section{II.3. Management (Managerial) Aspects}

In the field of management related to the industrial revolution in era 4.0 now, many theories have been issued, one of which is the theory of effective and efficient management of resources. In the period of 4.0 there were ways to transform conventional industry into industry 4.0, namely: (1) constructing a kind of operating system to maximise the effectiveness of policies and initiatives, (2) fluorishing concrete action plans that could be implemented for the transition to social and economic networks that could accommodate change innovative, (3) enhancing and outlining the strategies set by the central government to build social and economic systems that can respond to change flexibly, and (4) constract infrastructure to lead all initiatives [14].

\section{II.4. Aspects of the Higher Education System}

In the realm of higher education, one of the elements proclaimed by the Indonesian government in the face of the massive Industrial Revolution 4.0 is to encourage all State Universities (PTNs) to prepare a Distance Education System or Cyber University. Cyber University is one of the efforts made by universities to integrate all aspects of the higher education system into information technology, starting from the structure and learning system, curriculum, facilities, services, and facilities and infrastructure [15].

Indonesia is currently preparing its PTNs to go to a Cyber University, so it needs a lot of preparation starting from planning, implementing, controlling, and evaluating. However, in the planning stage, many problems arise because of the many things that need to be addressed to get to the next step [16].

In 2018, the Ministry of Research, Technology and Higher Education in the National Work Meeting (Rakernas) identified three essential elements that should be of concern to the Indonesian government in preparing Cyber University to welcome the Industrial Revolution 4.0, including (1) preparation of higher education learning systems, (2) institutional policy reconstruction, and (3) preparation of human resources [17]. 
Cyber University's learning system is very different from conventional learning in general. Teachers/lecturers and students are not in face to face directly but through intermediary media, whether it's video recording, teleconference, digital modul or even only through virtual world interactions. The concept of e-learning is one of the examples of the learning system implemented by Cyber University [18].

E-learning indeed requires various kinds of supporting equipment so that learning can be accessed by all student because the interaction between the lectures and the students that becomes the main differentiator from the conventional. They didn't meet directly but through the media. Likewise, policies that must be made by the institution or organisation concerned are related to their management. Then, human resources must also get attention because it is the person who took part in the continuation of the Cyber University [19].

\section{Methodology}

The methodology of this research used a qualitative method. The data collection used collected books, journal articles through systematic literature review, the unit analysis used the samples of the higher education system and Indonesian constitution, especially the organisation at the universities and Indonesian verdict.

\section{Results and Discussion}

\section{IV.1. Law}

\section{IV.1.1. Capacity and Capability Government Withstand the Disruption}

Along with the rapid thriving digital development, contributions from the government to face the digital era are urgently needed. Not only limited to giving suggestions to the private companies and regulate to move forward, but also provide convenience to the main point of the community and social as a whole. Even, there are too many findings, predictions, and projections for the future for legal developments on a world scale. However, there is still uncertainty to stand in this digital era, and economic growth becomes vulnerable to be reverse. To be specific, this is because the fast thriving of technological development is not directly equal to the growing of social development which it impacts on creating many causes such as social and also legal problems. Also, the digital realm, technologies, and its application have forcibly pushed the government as the foremost authority to take action to impose new regulation.

In the business sector, it was also significantly affected, such as the establishment of companies engaged in the field of Internet-based technology such as big data, cloud computing, and large industries such as application developers in developing and developed countries, both of which could be seen as opportunities but also challenges. However, the main problem is the debate about regulations related to the industry in the current era [20].

In the legal aspects, there is a lot of implications of disruption and revolution 4.0 towards law and regulation. As a salient example of this, the disruption and digital era have been changing the way of transactions and payment instrument. In the digital market, money could be altered by counterfeit money called cryptocurrency and blockchain which it has implicated in economy sectors because of its tax. In this research, the first and foremost of the novelty is the impacts of disruption era on trade law (blockchain realm) and intellectual property (IP) law which is focusing on AI [21].

\section{IV.1.2. Blockchain Realm and Indonesia's Regulation}

The disruption era has brought a new wave of groundbreaking in trade and investment which it evidences in a new method of the transaction in stock and blockchain realm invades almost all over the world because its convenient and untraceable are beneficial in some extent. Moreover, the trade and purchase in the world have been revolutionised in the way of payment because of cryptocurrencies and blockchain alteration. In this digital era, the phenomenon ofthe digital transaction is being debated by regulators and lawyers in all parts of the world. Even though cryptocurrency is seen as a development that has positive and possibilities, there are still many contradictions, and risks brought about by it.

Since the first platform of the cryptocurrency called Bitcoin by Satoshi Nakamoto and the others are becoming prominent and favourite instrument to alter the conventional transaction, some countries such as Japan, U.S., and Korea have been imposing regulation related to this in order to prevent unfavourable circumstances and therefore; China has been banning some of the cryptocurrencies. Not only developed countries who ban the new way of this transaction, but also developing countries aware of this development. In this research, Indonesia is the main subject and its regulation toward cryptocurrency and how to explain in the statute approach and tries to elaborate on a legal perspective.

Disruption era in Indonesia is one of the focusing challenges which the government puts more attention to it. Indonesia has been imposing the regulation relating to this. Before the statute of cryptocurrency is imposed, the government through Bank Indonesia in 2014 was announced that the cryptocurrency is not the legal payment instrument. However, the cryptocurrency becomes legal if it is utilised for the investment which it has been regulated by the minister of trade in ministerial regulation no. 99 in 2018 about general policy toward cryptocurrencies investment and the blockchain is protected and controlled by the Act of Indonesia Bank no. 18 in 2016 about Transaction and Payment.

In the 20 or even 30 years later in Indonesia, However, we can already foresee that blockchain technology will face various challenges from at least four different aspects, namely: (i) technical, (ii) marketing/business, (iii) behavioural/educational, and (iv) legal/regulatory [22].

\section{IV.1.3. Intellectual Property Law and Artificial Intelligence}

Firstly, as part of intellectual property, Artificial Intelligence has been used and profoundly protected by regulation in Indonesia. AI itself becomes usual in the digital industry right now. Almost all big companies such as Baidu, Facebook, and Google, for example, put more attention to the development of AI for inventing conveniences in appliances 
sector and others. However, it is brought the question of whether AI must be a challenge or opportunity in Indonesia.

In the future, AI will be altering several jobs in the industry such as lawyer, consultant, and consumer service who serve other people by advice. In the scope of legal and ethic, the government should make to accelerate digital technologies by the right policies. Therefore, in Indonesia constitution, AI still is considered uncertainty in intellectual property because there is no specific regulation about AI which focusing on Deep Learning, Fuzzy Logic, and implementation of the other concept. In Indonesia, for example, Patent, Trademark, and Innovation regulation have no concepting about AI although industries and companies have growth AI system and utilise in commercial purposes.

On the other hand, since Indonesia ratify Accession of Madrid Protocol by presidential decree no. 92 in 2017, AI became rightfully and used legally in Indonesia. Therefore, the World Intellectual Property Organisation tries to classify specifically about AI. However, Indonesia urges to impose new regulation related to this phenomenon. For preventing the unfavourable situation, government as policy-maker must manage the regulation planning by the concept of establishment of regulatarly sandboxes and wait and see like Singapore to withstand this disruption era.

\section{IV.2. Management Trajectory}

A glance with regards to filling the gaps in state of the art of management in these eras would elucidate the management trajectory, the resistance of industrial revolution 4.0 impacted changes dynamically to managing the people in the organisation, especially at the universities in the world. Besides, in the finance, marketing, operation of the system of higher education also changes every single day. Furthermore, we need to manage the turbulence of un-linear changes in every sector of the management area, for instance: human resource, strategic, operation, innovation, finance, and marketing at the system in the universities to tackle the collapse of higher education in these eras.

Moreover, the art of management in this era should be addressed to the locus in the system, because on the excellent system, it will be affected to repair to the many areas of management. Nevertheless, the problem is in that organisation need a prominent figure which leads every single decision correctly. With regards to the art of management in industrial revolution 4.0, [23] had a notion that the application of the current industry has shown that the relationship between objects, humans, and systems has become a more complicated, real-time, and dynamically optimised net. On the other hand, we need a harmonisation that includes the creation of new theories that harmonious with the realm, especially in industrial revolution 4.0 in the universities in the world.

Furthermore, there are some new findings in terms of the management of universities, in this case, is the University. First and foremost, the pattern of control and the shift in the university's paradigm, especially control in the world, is experiencing a change of value, it is interpreted in past history, for instance: long ago in the Middle East, Africa, and Asia world, Muslims studied at Mosques, but after universities appeared in the Western world, the Islamic world follows the pattern of Western education, namely by the establishment of the University of Al-Qarawiyyin in Morocco, the University of Sankore in West Africa, the University of Al-Azhar in Egypt, the University of AlQurtuba in Pakistan, the University of Islamic Medina in Saudi Arabia, the University of Umm Al-Qura Mecca in Saudi Arabia, the University of Islamic Indonesia in Indonesia, and so forth. Afterward, there is a paradigm shift, and the management of an educational institution that was initially in a Mosque moved to the University.

Secondly, the management pattern of universities is currently improving the proportion of values, especially the moral values associated with teachers/lecturers (educators), when the old students were studying in the Mosque, students were highly valued and took blessing from the teacher, but this is free the pattern of respect for students towards teachers began to increase degradation, i.e., currently students lack respect for their teachers, polite manners and manners start to decrease as well. This is related to the current development of the globalisation and the current flow of industrial revolution 4.0.

Thirdly, the pattern of electronic learning (elearning) management is increasingly encouraged currently, the researchers who have a perspective when e-learning is also replaced by virtual learning. The last but not least which important is the management pattern of the universities based on AI. The AI which contains big data (BD), blockchain (BC), cloud computing (CC), cryptocurrency (CC), data science (DS), deep learning (DL), machine learning (ML), the internet of things (IoT), and so on. With regards to the implementation of $\mathrm{AI}$ in various sectors provided so that it is necessary to maintain a pattern of university maintenance that will be based on good governance.

Besides that, with multiple technologies in various sectors, especially in the world of education, in this case, the university, the pattern of management of a higher education institution is increasingly sophisticated. With the increasingly advanced technology at a university, it will become easier for universities that have reached the world-class university (WCU) level. WCU is symbology for a world-class university that combines local wisdom from the organisational culture at the university with globalisation developing in this era.

The harmony between organisational culture and globalisation is represented in the pattern of implementing good governance in all sectors at the university. With the implementation of good management, the achievement of the vision and mission of the university will be more easily achieved. This is evidenced by the number of universities that obtain WCU degrees. Discussing, universities that have completed WCU degrees are universities that have high quality and have excellent governance.

The last but not least, in the era of industrial revolution 4.0 at this time also chaotic and collapsing universities could not keep up with the development of the times and developing technology. Many universities that collapsed were also suspected of chaos - some of these universities were due to the increasing number of students and universities entering, so the university became dead. In proverb (old saying), the university is assumed: "life is reluctant, dead do not want to." The pattern of good and right management in managing a university is the key to success in 
the continuing number of universities in the disturbed era. The ongoing disruption era has currently led to many innovations for updated universities and supported adaptations. A superior and competitive university will prepare changes that are approved and implemented amid an era that is not linear at the moment.

\section{IV.3. E-Governance}

Based on the plethora of previous research, we can summaries several requirements that must be fulfilled to realize a government information system (e-governance) that is capable and ready to face the industrial revolution era 4.0 which can be described as a critical success factor (CSF) shown in Figure 1.

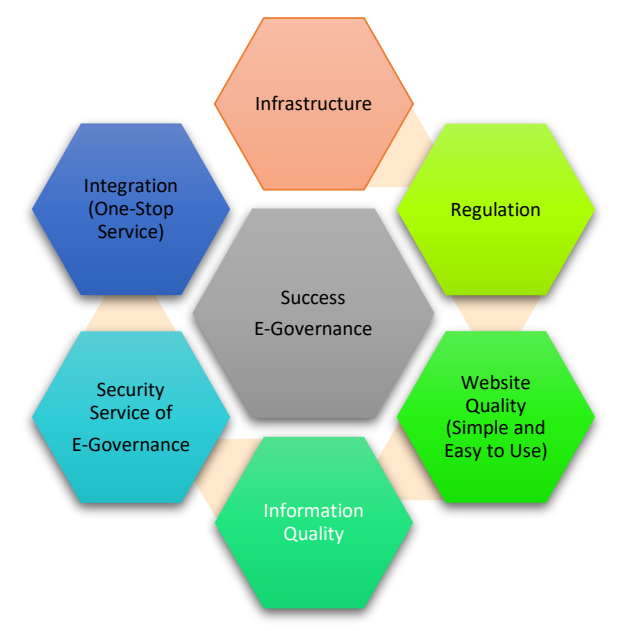

Fig. 1. Critical Success Factors (CSF)

Providing maximum service in the industrial revolution era 4.0 is a necessity that must be owned by the government, with the presence of e-governance expected to be able to answer these challenges to provide better, more transparent, more accountable services and also reduce the complexity of bureaucracy. If the e-governance can be implemented thoroughly and evenly, it can invite business opportunities and investors between the government and stakeholders.

\section{IV.3.1. Information Quality}

The quality of information provided by the government, in this case, is paramount considering that through the concept of e-governance, it is hoped that government policies can be accessed by all people so that the programme launched by the government can be run and beneficial to the community. Information can be available 24 hours, without knowing holidays and without waiting for the government office to open. E-governance can also support the government's performance to be more efficient by increasing communication between the government and the business and industry sectors. The community can also provide complaints and suggestions to the government directly without going through an intermediary.

IV.3.2. E-Governance Security
In general, there is almost no information that is certain to be safe. But with the increase in data presented by the government whose purpose is to provide services, the higher the security challenges of information. Information security is generally related to the availability of information (availability), completeness of the data (integrity), and information confidentiality (confidentiality). The government issued a regulation (PP no. 82 of 2012) concerning the implementation of systems and electronic transactions. This PP regulates security issues, which governs that each organizer must carry out a track record and audit of all activities. The organizer is required to safeguard electronic system components.

\section{IV.3.2.1. Integrated}

Various service units are combined into one service portal which will be accessible to the community at one time simultaneously.

\section{IV.3.2.2. Infrastructure}

Facilities and infrastructure to support the implementation of e-governance, such as software and hardware, policies, procedures, networks, and data. All these things must be fulfilled so that no imbalance can cause uneven information and communication technology infrastructure.

\section{IV.3.2.3. Regulation}

Supporting regulations for the implementation of egovernance in Indonesia can be found, for instance:

- Presidential Instruction no. 3 of 2003 concerning national policies and strategies for developing e-government,

- Government Regulation of the Republic of Indonesia no. 82 of 2012, concerning the implementation of systems and electronic transactions, and

- Law no. 14 of 2008 concerning public information disclosure.

\section{IV.3.3. Website Quality}

E-governance services can also be measured by the quality of websites provided by the government for public access. Then how easy is e-governance to be used and accessed by the community, so that it can increase public confidence in e-government regarding the risk of harm or doubt during the online service process. Facilitate users, from beginners or who already have experience that aims to accelerate interactions so that the system can perform user activities more quickly and on time.

So that the fulfillment of indicators such as the author described above is expected to provide maximum service with the implementation of e-governance in the industrial revolution era 4.0 is a must that must be owned by the government, with the presence of e-government is expected to be able to answer these challenges to provide better services, more transparent, more accountable and also reduces the complexity of the bureaucracy. If e-governance can be implemented thoroughly and evenly, it can invite business opportunities and investors between the government and stakeholders.

\section{IV.4. The System of Higher Education (HE) \\ IV.4.1. Problems Encountered by Cyber University}

The difficulties encountered in creating a Cyber University in Indoneisa are not tricky, the proof is that there have been several universities that have started implementing 
the Cyber University's sistem like, one of which is the Universitas Terbuka (UT). However, it is not an easy thing also to make it happen. A series of busnesses that are mutually supportive, continuous and consistent are needed to make it happen optimally.

According to [25], the problem faced in creating a Cyber University includes aspects of infrastructure, curriculum, interaction, learner, administration, and the systems.

Infrastructure is indeed the main problem faced by conventional universites. Some sophisticated equipment is needed to support the realisation of universitirs that support distance learning (e-learning) — one of them, namely the internet. Research conducted by Sujarwoto \& Tampubolon (2016) states that there is a gap between internet acces that is not evenly distributed throughout Indonesia, thus affecting the socio-economic, household, and related districts. The existence of gaps in telecommunications infrastructrue, especially the internet, has become one of the obstacles to the realisation of Cyber Universities in Indonesia.

Secondly, in the field of curriculum, as the core of learning, of course, must adjust to the learning system that is different for the conventional one. Thus, an adjustment must be made in the context of implementing a new learning system. Cyber University learning is thick with the word of 'long distance', in addition to providing easy access that doesn't recognise distance and time, but there are several numbers of things that concern the problem faced, such as learning that is less interesting, because learning has been designed in such a way by lecturers, so the result depends on the design and nature of the lecturer in teaching. Also, the instruction given will be perceived by each student differently, so that there is a lack of clarity in learning guidelines. The instructional materials provided will certainly be very limited to the selected content. And the most important thing is how to evaluate students, because it is different from the conventional one, so the assessment will undoubtedly be different, and equality of perception will be very difficult to achieve.

Related to the interactions carried out, because of the different distance and time, the communications between two parties must be limited and experience various problems. Distace learning relies heavily on media, so students only can learn without being able to get feedback from the lecturers. Moreover, the difference in language. Also, learning with this method has difficulty teaching students to learn in groups, ranging from dividing groups, and how to evaluate them in the right way.

Then, aspects related to individuals who learn, students. Not all students have the same ability to operate electronic devices (gadgets). Plus learning that is done remotely will be very passive, unable to ask directly the obstacles faced by students, so students become less active in education. And this also results in students who are only focused on learning without actively asking questions, digging deeper into the material. And because this is distance learning, the laziness in students will be on high scores.

It is associated with the policies of institutions or organisations, of course not separated from administration and systems. The problem faced in this aspect is the lack of preparation or experience in dealing with new things. This is also related to the human resources that manage it so that the system is operated will be less than optimal. Related to this, there have been discussed in the previous sub points.

\section{IV.4.2. Suggestions from the Problems Encountered by Cyber University}

Recommendations from the problems encountered based on the result of research of [26]. Firstly, facing issues that are experienced in terms of infrastructure aspects indeed must involve many stakeholders, such as Ministers of Research, Technology and Higher Education. That way, support in the creation of supporting infrastructure can be monitored and realised with direction. Focusing on the development of telecommunications infrastructure with highquality internet and evenly distributed can help the problems faced in terms of support.

In terms of curriculum, various suggestions that can be submitted to overcome multiple problems faced by Cyber University include using animation or hyperlinks in the context of a more detailed explanation of the material explained by the lecturer. Then, by offering courses privately, it will significantly help students to learn the stuff they want to learn to be more in-depth.

If it concerns interactions in learning, online learning can be an alternative that can be used to overcome distance learning that is one-way (offline). Lecturers can design such lectures to be more interactive with a variety of different languages, so students can choose the language they understand.

Associated with the learner or student, indeed this is related to students personally. Does he/she need this lecture or not. With students choosing what they want to learn, it means they know what their needs are. So that students can understand and can prepare to study online. And because all decisions are in the hands of students, then he can decide how to behave and adjust to his learning style, and foster an attitude of active learning. And if appropriately implemented, knowledge will become more active-research conducted by [27] which states that using e-learning will increase student activitiy in learning.

For administrative and system issues, indeed all of this requires careful planning. Various policies and operating systems must be planned seriously beforehand, whether it is from mirroring the country that has succeeded in making it happen or doing various innovations that support the creation of small steps in achieving a cyber university.

For more details, here are the results of research condected by [28-30] for problems and suggestion by Cyber University, which will be shown in table 1 below.

\begin{tabular}{|c|c|c|}
\hline & Problem Type & Suggestion \\
\hline Infrastructure & $\begin{array}{l}\text { 1. The internet } \\
\text { bandwidth, } \\
\text { 2. The internet } \\
\text { quality, } \\
\text { 3. High internet } \\
\text { fee, } \\
\text { 4. Human } \\
\text { resources } \\
\text { capital, } \\
\text { Technique } \\
\text { support, and }\end{array}$ & 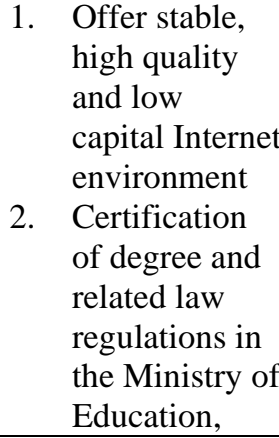 \\
\hline
\end{tabular}




\begin{tabular}{|c|c|c|}
\hline & Problem Type & Suggestion \\
\hline & $\begin{array}{l}\text { 6. Certification of } \\
\text { credits and } \\
\text { degrees. }\end{array}$ & 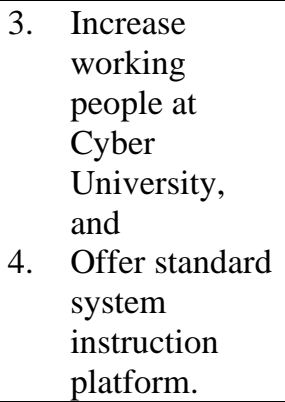 \\
\hline Curriculum & $\begin{array}{l}\text { 1. } \begin{array}{l}\text { Courses are not } \\
\text { attractive, } \\
\text { 2. }\end{array} \\
\text { materials are } \\
\text { restricted, } \\
\text { 3. Unproper } \\
\text { instruction } \\
\text { design, } \\
\text { 4. The problem of } \\
\text { the link } \\
\text { between } \\
\text { sessions, and } \\
\text { Disputes on } \\
\text { evaluation way. }\end{array}$ & $\begin{array}{l}\text { 1. } \begin{array}{l}\text { Blackboard, } \\
\text { animation and } \\
\text { hyperlink } \\
\text { explanation, }\end{array} \\
\text { 2. Offer practical } \\
\text { course content, } \\
\text { 3. Offer } \\
\text { individual } \\
\text { learning } \\
\text { course, } \\
\text { 4. } \begin{array}{l}\text { Regulated } \\
\text { prepared }\end{array} \\
\text { courses, } \\
\text { 5. Apply } \\
\text { encouraging } \\
\text { and rewarding } \\
\text { measures, and } \\
\text { Apply to form } \\
\text { evaluation. }\end{array}$ \\
\hline Interaction & $\begin{array}{l}\text { 1. Lack of human } \\
\text { interaction, } \\
\text { The need for } \\
\text { synchronous } \\
\text { communication, } \\
\text { 3. The problem of } \\
\text { the word } \\
\text { communication, } \\
\text { 4. Misunderstandi } \\
\text { ng of online } \\
\text { communication, } \\
\text { 5. Hard to } \\
\text { archieve group } \\
\text { consensus, } \\
\text { 6. How to divide } \\
\text { into groups, and } \\
\text { 7. How to evaluate } \\
\text { groups. }\end{array}$ & $\begin{array}{l}\text { 1. } \begin{array}{l}\text { Hold activites: } \\
\text { Internet Little } \\
\text { Angel, Online } \\
\text { Study Circle, } \\
\text { 2. Apply } \\
\text { strategies to } \\
\text { promote } \\
\text { interaction, } \\
\text { 3. Use diversified } \\
\text { communicatio } \\
\text { n methods, } \\
\text { 4. Reference } \\
\text { principles of } \\
\text { division into } \\
\text { groups, } \\
\text { Consider } \\
\text { individual and } \\
\text { group } \\
\text { contribution, } \\
\text { and } \\
\text { Teach } \\
\text { cooperative } \\
\text { skills and offer } \\
\text { promoters. }\end{array}\end{array}$ \\
\hline Learner & $\begin{array}{l}\text { 1. } \begin{array}{l}\text { Burden from } \\
\text { work and } \\
\text { family, } \\
\text { 2. Basic computer } \\
\text { ability, }\end{array}\end{array}$ & $\begin{array}{l}\text { 1. } \begin{array}{l}\text { Make sure } \\
\text { need and } \\
\text { practive } \\
\text { thoroughly, }\end{array} \\
\text { 2. Understand } \\
\text { and get ready }\end{array}$ \\
\hline
\end{tabular}

\begin{tabular}{|c|c|c|}
\hline & Problem Type & Suggestion \\
\hline & $\begin{array}{l}\text { 3. } \begin{array}{l}\text { Not positive } \\
\text { and active, }\end{array} \\
\text { 4. } \begin{array}{l}\text { Don't ask } \\
\text { questions, }\end{array} \\
\text { 5. Only study but } \\
\text { no contribution, } \\
\text { and } \\
\text { 6. Self laziness. }\end{array}$ & $\begin{array}{l}\text { for online } \\
\text { learning, } \\
\text { Adjust attitude } \\
\text { and learning } \\
\text { style, and } \\
\text { 4. Form active } \\
\text { learning } \\
\text { attitude. }\end{array}$ \\
\hline Administration & $\begin{array}{l}\text { 1. The problem of } \\
\text { school } \\
\text { orientation, } \\
\text { 2. Lack of } \\
\text { previous } \\
\text { preparation, } \\
\text { 3. Lack of human } \\
\text { resources } \\
\text { support, and } \\
\text { 4. The issue of } \\
\text { service quality. }\end{array}$ & $\begin{array}{l}\text { 1. } \begin{array}{l}\text { Previous } \\
\text { planning }\end{array} \\
\text { courses and its } \\
\text { direction, } \\
\text { 2. } \begin{array}{l}\text { Plan proper } \\
\text { conditions of } \\
\text { entering }\end{array} \\
\text { school and } \\
\text { evaluation } \\
\text { system, } \\
\text { To choose } \\
\text { appropriate } \\
\text { online } \\
\text { learners, } \\
\text { Reply } \\
\text { messages in } 24 \\
\text { hours, and } \\
\text { Set up a place } \\
\text { to give exams } \\
\text { flexibly. }\end{array}$ \\
\hline System & $\begin{array}{l}\text { 1. } \begin{array}{l}\text { System opration } \\
\text { and usage, }\end{array} \\
\text { 2. } \begin{array}{l}\text { Immedaite } \\
\text { discussion } \\
\text { tools, }\end{array} \\
\text { 3. } \begin{array}{l}\text { Category of } \\
\text { discussion }\end{array} \\
\text { boards, and } \\
\text { 4. } \begin{array}{l}\text { Related } \\
\text { software usage. }\end{array}\end{array}$ & $\begin{array}{l}\text { 1. } \begin{array}{l}\text { Offer step-by- } \\
\text { step operation }\end{array} \\
\text { instruction, } \\
\text { 2. Offer } \\
\text { intellectual } \\
\text { individual } \\
\text { learning } \\
\text { environment, } \\
\text { Offer } \\
\text { intellectual } \\
\text { instruction } \\
\text { guidance and } \\
\text { diagnosis, } \\
\text { Offer } \\
\text { instruction } \\
\text { area of popular } \\
\text { questions and } \\
\text { similar } \\
\text { software, } \\
\text { Offer } \\
\text { cooperative } \\
\text { environtment } \\
\text { and } \\
\text { mechanism, } \\
\text { Offer alarm } \\
\text { progress } \\
\text { function, } \\
\text { Develop a } \\
\text { voice } \\
\text { communicatio }\end{array}$ \\
\hline
\end{tabular}




\begin{tabular}{|c|c|c|}
\hline & Problem Type & Suggestion \\
\hline & & $\begin{array}{l}\mathrm{n} \text { interface, } \\
\text { and } \\
\text { 8. } \\
\text { Classify } \\
\text { discussion } \\
\text { board } \\
\text { according to } \\
\text { topics. }\end{array}$ \\
\hline
\end{tabular}

\section{Conclusion}

By way of conclusion, a literature review of disruption era in Indonesia has been proposed to fill the gaps, and the techniques to tackle the resistance of industrial revolution 4.0 also had been suggested in order to contribute to the body of knowledge of industrial revolution 4.0 to link to each other that includes the new theories, conceptualisation, and practices in the fields: the law, electronic governance, management trajectory, and system of higher education in Indonesia.

\section{References}

[1] Asawa, A. (2018). A study of Digital Disruption, Innovation, and Economic Transformation. Artificial Intelligence: The Star of the Digital Galaxy. Amazon Kindle: United States of America.

[2] Altameem, T., Zairi, M., \& Alshawi, S. (2006). ' Critical Success Factors of E-Governance: A Proposed Model for E-Governance Implementation, 200 Innovations in Information Technology, Dubai, 2006, pp. 1-5.

[3] Darmayanti, T., Setiani, M. Y., \& Oetojo, B. (2007). Elearning pada Pendidikan Jarak Jauh: Konsep yang Mengubah Metode Pembelajaran di Perguruan Tinggi di Indonesia. Jurnal Pendidikan Terbuka dan Jarak Jauh.

[4] Kementerian Riset, Teknologi, dan Pendidikan Tinggi (Ristekdikti). (2018). Rapat Kerja Nasional-Ristek Dikti di Era Revolusi Industri 4.0. Universitas Sumatera Utara.

[5] Lin, K.M. \& Chen, N.S. (2001). Exploring Learning Problems of Cyber University. IEEE. http://doi.org/10.1109/ICALT.2001.943947.

[6] Mougayar, W. (2016). The Business Blockchain: Promise, Practice, and Application of the Next Internet Techology. Wiley: New York.

[7] Pangondian, R.A., Santosa, P. I., \& Nugroho, E. (2019). Faktor Yang Harus Dipenuhi Oleh Sistem Informasi Pemerintahan (E-Governance) Dalam Menghadapi Disrupsi Revolusi Industri 4.0., Universitas Gadjah Mada.

[8] Ratnasari, A. (2012). Studi Pengaruh Penerapan ELearning terhadap Keaktifan Mahasiswa dalam Kegiatan Belajar Mengajar-Studi Kasus Universitas Mercu Buana Jakarta. Seminar Nasional Aplikasi Teknologi Informasi. ISSN: 1907-5022.

[9] Sujarwoto, S. \& Tampubolon, G. (2016). Spatial Inequality and the Internet Divide in Indonesia 20102012. Telecommunications Policy, 40(7), 602-616. http://doi.org/10.1016/j.telpol.2015.08.008.
[10] Sung, T.K. (2018). Industry 4.0: A Korea Perspective. Technological Forecasting \& Social Change, vol. 135, pp. $40-45$.

[11] Tuoa, J., Simota, J., \& Steiner, F. (2017). Aspects of risk management implementation for Industry 4.0. $27^{\text {th }}$ of International Conference on Flexible Autmation and Intelligent Manufacturing, vol. 11, pp. 1223-1230.

[12] Topping, C. J., Dalby, L., \& Skov, F. (2016). Landscape structure and management alter the outcome of a pesticide ERA: evaluating impacts of endocrine disruption using the ALMaSS European Brown Hare model. Science of the Total Environment, 541, 14771488.

[13] McLaurin, K. A., Li, H., Booze, R. M., \& Mactutus, C. F. (2019). Disruption of timing: NeuroHIV progression in the post-cART era. Scientific reports, 9(1), 1-18.

[14] Godden, L., \& Tehan, M. (2016). REDD+: climate justice and indigenous and local community rights in an era of climate disruption. Journal of Energy \& Natural Resources Law, 34(1), 95-108.

[15] Grinberg, I. (2018). International Taxation in an Era of Digital Disruption: Analysing the Current Debate. Georgetown University Law Center.

[16] Victor, R., \& Ogbeibu, A. E. (1986). Recolonisation of macrobenthic invertebrates in a Nigerian stream after pesticide treatment and associated disruption. Environmental Pollution Series A, Ecological and Biological, 41(2), 125-137.

[17] Dovey, K. A. (2005). Leadership education in the era of disruption: what can business schools offer?. International Journal of Leadership Education.

[18] Sufirmansyah, S. (2019). Actualisation of Andragogical Learning Strategies for Higher Education in Disruption Era. Didaktika Religia, 6(2), 351-370.

[19] Oliveira, E., Barata, C., \& Piña, B. (2016). Endocrine disruption in the omics era: new views, new hazards, new approaches. The Open Biotechnology Journal, 10(1).

[20] Lasi, H., Fettke, P., Kemper, H. G., Feld, T., \& Hoffmann, M. (2014). Industry 4.0. Business \& information systems engineering, 6(4), 239-242.

[21] Lee, J., Bagheri, B., \& Kao, H. A. (2015). A cyberphysical systems architecture for industry 4.0-based manufacturing systems. Manufacturing letters, 3, 1823.

[22] Stock, T., \& Seliger, G. (2016). Opportunities of sustainable manufacturing in industry 4.0. Procedia Cirp, 40, 536-541.

[23] Rüßmann, M., Lorenz, M., Gerbert, P., Waldner, M., Justus, J., Engel, P., \& Harnisch, M. (2015). Industry 4.0: The future of productivity and growth in manufacturing industries. Boston Consulting Group, 9(1), 54-89.

[23] Gilchrist, A. (2016). Industry 4.0: the industrial internet of things. Apress.

[24] Lee, J., Kao, H. A., \& Yang, S. (2014). Service innovation and smart analytics for industry 4.0 and big data environment. Procedia Cirp, 16(1), 3-8.

[25] Jazdi, N. (2014, May). Cyber physical systems in the context of Industry 4.0. In 2014 IEEE international 
conference on automation, quality and testing, robotics (pp. 1-4). IEEE.

[26] Gorecky, D., Schmitt, M., Loskyll, M., \& Zühlke, D. (2014, July). Human-machine-interaction in the industry 4.0 era. In 2014 12th IEEE international conference on industrial informatics (INDIN) (pp. 289294). IEEE.

[27] Brettel, M., Friederichsen, N., Keller, M., \& Rosenberg, M. (2014). How virtualisation, decentralisation and network building change the manufacturing landscape: An Industry 4.0 Perspective. International journal of mechanical, industrial science and engineering, 8(1), 37-44.

[28] Xu, L. D., Xu, E. L., \& Li, L. (2018). Industry 4.0: state of the art and future trends. International Journal of Production Research, 56(8), 2941-2962.

[29] Qin, J., Liu, Y., \& Grosvenor, R. (2016). A categorical framework of manufacturing for industry 4.0 and beyond. Procedia Cirp, 52, 173-178.

[30] Hofmann, E., \& Rüsch, M. (2017). Industry 4.0 and the current status as well as future prospects on logistics. Computers in industry, 89, 23-34. 